\title{
What is good about Sri Lankan homegardens with regards to food security? A synthesis of the current scientific knowledge of a multifunctional land-use system
}

Eskil Mattsson, Madelene Ostwald and SP Nissanka

Journal Article

Tweet

N.B.: When citing this work, cite the original article.

This is a copy of the original publication which is available at www.springerlink.com:

Eskil Mattsson, Madelene Ostwald and SP Nissanka, What is good about Sri Lankan homegardens with regards to food security? A synthesis of the current scientific knowledge of a multifunctional land-use system, Agroforestry Systems, 2017.

http://dx.doi.org/10.1007/s10457-017-0093-6

Copyright: Springer Verlag (Germany)

http://www.springerlink.com/?MUD=MP

Postprint available at: Linköping University Electronic Press

http://urn.kb.se/resolve?urn=urn:nbn:se:liu:diva-137665

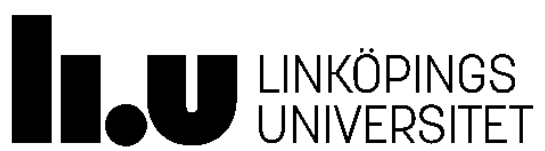


What is good about Sri Lankan homegardens with regards to food security? - A synthesis of the current scientific knowledge of a multifunctional land-use system

\author{
Mattsson, E. ${ }^{1}$, Ostwald, M. ${ }^{1,2}$, Nissanka, S.P. ${ }^{3}$ \\ ${ }^{1}$ Centre for Environment and Sustainability, Chalmers University of Technology, 41296 Göteborg, \\ Sweden. E-mail: eskil.mattsson@chalmers.se
}

${ }^{2}$ Centre for Climate Science and Policy Research, Department of Thematic Studies/Environmental Change, Linköping University, 58183 Linköping, Sweden. E-mail: madelene.ostwald@liu.se

${ }^{3}$ Department of Crop Science, Faculty of Agriculture, University of Peradeniya, Peradeniya, Sri Lanka. Email: spn@pdn.ac.lk

\title{
Abstract
}

Recently, there has been growing interest in agroforestry systems due to their great potential to mitigate threats to household food and nutrition security from soaring food prices but also as carbon sinks. In Sri Lanka, smallholder farms such as homegardens constitute a majority of Sri Lanka's total annual crop and timber production. Despite Sri Lankan homegardens being considered desirable and sustainable land-use systems, their role in food and nutrition security is not yet entirely understood. By synthesising scientific articles and grey literature we sought the link between food security and homegardens by quantifying their products or services and ascertaining whether food security characteristics are assessed as direct or indirect impacts. The results show that $27 \%$ of 92 identified articles directly quantified aspects that are relevant to food security. Another $51 \%$ of the articles quantified indirect aspects that have relevance for food security, including climate, soil, ecosystem services, structural and floristic diversity and economic aspects. Twenty-two percent of the articles were categorised as being qualitative or conceptual and contained no direct assessments or quantification of food security. The presence of significant merits from homegardens includes providing food security throughout the year at low-cost while sustaining numerous ecosystem services. This benefits particularly the poor farmers. However, many studies are descriptive and only provide location-specific information on single research focuses such as plant species, yield and management. There are few comparisons with crop land, forests or other production systems, and there is even less empirical evidence and quantification of the food security and other benefits. Seven areas where more scientific focus would be beneficial are identified. Homegardens are strong in national policies and to reach a greater level of efficiency within these activities our findings suggest more emphasis on a higher degree of inclusiveness of relevant stakeholders and long-term engagements with context specific guidance.

Keywords: agroforestry; Sri Lanka; nutrition; diversity; intensification; trees; crops; landscape

Introduction

By the year 2030, the planet will have to support an additional 1.15 billion people, $90 \%$ of which will reside in developing countries (UN DESA 2015). Aligned with efforts to slow population growth, intensify agriculture, reduce food waste and improve value chains, there is a need to increase the products and services from limited land resources. Therefore, in this paper, we examine the potential of multifunctional land-use systems to enhance food security. Multifunctional land-use systems are often presented as a remedy to intensify production, improve livelihoods and sustain more resilient ecosystems. Hence, policy makers and scientists now promote these land-use systems as an attractive alternative to intensive farming and commercial forestry practices (e.g., Kumar et al. 2012;

Bustamante et al. 2014; van Noordwijk et al. 2014; Santika et al. 2015). 
Recently, agroforestry systems (AFS) have been presented as key multifunctional land-use practices due to their great potential for mitigating and adapting to climate change and their role in minimising threats to household food and nutrition security from soaring food prices (Minang et al. 2012; Galhena et al. 2013; Mohri et al. 2013; Minang et al. 2014). By combing traditional knowledge with new technologies, agroforestry practices can also contribute to the transformation needed to achieve several sustainable development goals (Mbow et al. 2014a).

Over the last decade, Sri Lanka has achieved food security for everyone in the nation by increasing food production and ensuring equal distribution (Marambe et al. 2015). Smallholder farming account for more than $80 \%$ of Sri Lanka's total annual crop and timber production, a large percentage of which are grown in agroforestry homegardens (World Bank; CIAT 2015).

Despite Sri Lankan homegardens being considered desirable and sustainable land-use systems, scientific evidence of their role in food security is, however, not yet entirely understood. Therefore, by synthesising scientific articles we aim to answer the following questions:

- What is the focus of the scientific material and where are the knowledge gaps to understand the relationship between Sri Lankan homegardens and food security?

- How is food security and nutrition in homegardens assessed in terms of quantifying their products or services or by comparing them with alternative land-use systems?

- What characteristics are assessed and are these assessed as direct or indirect impacts, in relation to food security?

Based on the outcome of our analysis, we ultimately discuss the type of policies that exists and how these activities can enhance homegarden development and food security.

Homegardens as multifunctional land-use systems in Sri Lanka In contrast to monospecific production systems, homegarden systems are production models that combine natural ecological functions with the socio-economic wellbeing of the families that maintain them (Kumar 2006) (Table 1). In Sri Lanka, homegardens have been defined as a complex sustainable land-use system that combines multiple farming components, such as annual and perennial crops, livestock and occasionally fish, which provides environmental services, resources for household needs, as well as employment and income generation opportunities (Weerahewa et al. 2012). FAO (2009) estimated that homegardens covered about $13 \%$ of the land area while recent data (AgStat 2016) reported a much higher value $-22 \%$. Homegardens serve as important links to other agricultural and natural landscapes, delivering a diverse landscape mosaic (Hochegger 1998; Kudavidanage et al. 2011). The number of homegardens has grown by approximately $2 \%$ annually due to the establishment of new settlements and the fragmentation of existing homegardens. Approximately $52 \%$ of the country's homegarden owners are small-scale farmers performing semisubsistence farming activities usually on less than 0.5 hectares of land (World Bank; CIAT 2015). Homegardens are mostly privately owned and are managed through family labour using technologies that rely on rich local knowledge systems (Pushpakumara et al. 2010; 2012). 
Table 1. Summary of the relative attributes of a land-use continuum in the tropics.

\begin{tabular}{|c|c|c|c|c|c|c|}
\hline \multicolumn{7}{|c|}{ Type of land use } \\
\hline \multirow[b]{2}{*}{ Attributes } & \multicolumn{2}{|c|}{ Intensive monoculture } & \multicolumn{2}{|c|}{ Multifunctional } & \multicolumn{2}{|c|}{ Forests } \\
\hline & $\begin{array}{l}\text { Annual } \\
\text { crops }\end{array}$ & $\begin{array}{l}\text { Perennial } \\
\text { crops }\end{array}$ & $\begin{array}{l}\text { Simple } \\
\text { agroforests }\end{array}$ & $\begin{array}{l}\text { Homegardens } \\
\text { and complex } \\
\text { multi-strata } \\
\text { systems }\end{array}$ & $\begin{array}{l}\text { Secondary } \\
\text { forests }\end{array}$ & $\begin{array}{l}\text { Primary } \\
\text { forests }\end{array}$ \\
\hline Diversity & Low & Low & Medium & High & Very high & Very high \\
\hline Soil biota & Low & Low & Medium & High & High & Very high \\
\hline $\begin{array}{l}\text { Ecosystem } \\
\text { Services }\end{array}$ & Low & $\begin{array}{l}\text { Low- } \\
\text { medium }\end{array}$ & Low-high & Medium-high & High & Very high \\
\hline $\begin{array}{l}\text { Loss rate of } \\
\text { soil carbon } \\
\text { (decomposition) }\end{array}$ & $\begin{array}{l}\text { High-very } \\
\text { high }\end{array}$ & Medium & Medium & Low-medium & $\begin{array}{l}\text { Low- } \\
\text { medium }\end{array}$ & Low \\
\hline $\begin{array}{l}\text { Nutrient outputs } \\
\text { (leaching/other } \\
\text { losses) }\end{array}$ & High & Medium & Medium & Low & Low & Very low \\
\hline $\begin{array}{l}\text { Fossil fuel } \\
\text { inputs/subsidies } \\
\text { (carbon costs) }\end{array}$ & High & $\begin{array}{l}\text { Medium- } \\
\text { high }\end{array}$ & $\begin{array}{l}\text { Low- } \\
\text { medium }\end{array}$ & Low & Zero & Zero \\
\hline $\begin{array}{l}\text { Above ground } \\
\text { carbon stock }\end{array}$ & Low & Low-high & Low-high & Medium-high & $\begin{array}{l}\text { Medium- } \\
\text { high }\end{array}$ & Very high \\
\hline $\begin{array}{l}\text { Below ground } \\
\text { carbon stock }\end{array}$ & Low & Low-high & Low-high & Medium-high & $\begin{array}{l}\text { Medium- } \\
\text { high }\end{array}$ & Very high \\
\hline
\end{tabular}

Source: Adapted from Kumar (2006) and Pushpakumara et al. (2012)

Homegardens are distributed in all districts of Sri Lanka, varying from $2.4 \%$ of the total land area of the Manner district to $36.2 \%$ of the total land area in the Matara district. Homegarden prevalence is typically high in those districts with high population density and where forest cover is low, i.e., wet zones. This is evidenced by the percentage of homegardens exceeding the national average (13-22 \%) primarily in the wet zone of Sri Lanka, whereas forest cover exceeds the national average $(23.5 \%)$ primarily in the districts that belong to the country's dry zones (Table 2). 
Dry zone homegardens are larger than wet zone homegardens and have a comparatively low tree density. The biomass production in dry zone homegardens are often limited by moisture, leading to a weaker capacity to replenish soil fertility by organic matter inputs than wet zone homegardens (Sangakkara and Frossard 2016). Wet zone homegardens have a higher level of plant diversity and a denser canopy structure than dry zone homegardens due to climatic conditions favourable for high growth (FAO 2009; Pushpakumara et al. 2010; Ali and Mattsson 2016). This is also the zone with a high population density, low land availability, a developed infrastructure and high possibility for offfarm jobs. In the Kandyan region, wet zone homegardens are also referred to as Kandyan forest gardens due to their structural resemblance to natural forests (Jacob and Alles 1987; Perera and Rajapakse 1991; McConnell 2003; Mohri et al. 2013). Kandyan homegardens offer economic stability to farmers and provide a significant amount (30-50 \%) of household income (Pushpakumara et al. 2010). Senanayake (1987) also reported that the bird and soil fauna within Kandyan homegardens is rich and comparable to surrounding natural forests.

Table 2. Land area, population density, forest and homegarden cover of all administrative districts of Sri Lanka. Tree canopy cover is defined by adding the forest and homegarden cover areas. Adapted from IUCN and MENR (2007), FSMP (1995) and Pushpakumara et al. (2012).

\begin{tabular}{lllll}
\hline District & $\begin{array}{l}\text { Area (sq } \\
\mathbf{k m})\end{array}$ & $\begin{array}{l}\text { Population } \\
\text { density (per } \\
\mathbf{s q ~} \mathbf{~ k m})\end{array}$ & $\begin{array}{l}\text { Forest cover } \\
\text { (\% of land } \\
\text { area) }\end{array}$ & $\begin{array}{l}\text { Homegarden } \\
\text { cover (\% of } \\
\text { land area) }\end{array}$ \\
\hline Ampara & 4,318 & 143 & 37.5 & 4.1 \\
\hline Anuradhapura & 7,034 & 111 & 35.0 & 8.0 \\
\hline Badulla & 2,803 & 294 & 19.0 & 17.7 \\
\hline Batticaloa & 2,686 & 204 & 21.0 & 4.2 \\
\hline Colombo & 656 & 3,631 & 2.8 & 13.1 \\
\hline Galle & 1,635 & 629 & 13.0 & 22.1 \\
\hline Gampaha & 1,386 & 1,523 & 0.3 & 25.2 \\
\hline Hambantota & 2,579 & 210 & 20.5 & 15.1 \\
\hline Jaffna/Kilinochchi & 2,218 & 337 & 1.1 & 26.5 \\
\hline Kalutara & 1,588 & 688 & 13.0 & 20.1 \\
\hline Kandy & 1,906 & 704 & 17.0 & 30.4 \\
\hline Kegalle & 1,693 & 468 & 9.5 & 23.2 \\
\hline Kurenegala & 4,813 & 311 & 5.0 & 15.1 \\
\hline Mannar & 1,985 & 50 & 60.0 & 2.4 \\
\hline Matale & 1,993 & 233 & 40.5 & 11.7 \\
\hline Matara & 1,282 & 620 & 16.0 & 26.2 \\
\hline Moneragala & 5,545 & 75 & 40.5 & 9.9 \\
\hline Mullaitivu & 2,517 & 56 & 60.0 & 6.6 \\
\hline Nuwara Eliya & 1,720 & 423 & 24.5 & 5.3 \\
\hline Polonnaruwa & 3,224 & 117 & 38.0 & 10.6 \\
\hline Puttalam & 3,013 & 245 & 25.0 & 21.5 \\
\hline Ratnapura & 3,255 & 325 & 20.0 & 15.8 \\
\hline Trincomalee & 2,631 & 147 & 48.0 & 7.2 \\
\hline Vavuniya & 1,967 & 74 & 51.0 & 10.1 \\
\hline Total (all districts) & 65,610 & 314 & 23.5 & 13.1 \\
\hline & & & & \\
\hline
\end{tabular}

Several governmental programmes in Sri Lanka have included homegardens as key components to support food and nutrition security. Recent initiatives by the government to promote food security, included promoting homegardens as a way to achieve self-sufficiency in vegetable production and 
reducing vegetable prices by providing free seeds, fertilisers and technical advice to smallholder farmers. Within the current Food Production National Programme aimed at eliminating poverty and making the country self-sufficient in food, homegardens play an important role in food production as people are encouraged to cultivate vegetables and multipurpose tree species (food and fruits) in their own backyards for their daily consumption. For example, the Ministry of Agriculture has established the goal of doubling the daily per person consumption of fruits and vegetables from the present 100 grams to 200 grams (Government of Sri Lanka 2015). Homegardens are also indirectly referenced in Sri Lanka's Intended Nationally Determined Contributions (INDCs) to the United Nations Framework Convention on Climate Change (UNFCCC 2016) and have a prominent role in meeting climate mitigation goals under Sri Lanka's UN REDD+ programme to reduce emissions from deforestation and forest degradation (UN-REDD 2015). Homegardens are also featured in Sri Lanka's National Adaptation Plan for Climate Change (NAP) for 2016-2025 as a learning ground to promote traditional methods of biodiversity conservation for increased crop resilience (Ministry of Mahaweli Development and Environment 2015).

Materials and methods

Our synthesis focused on identifying the current knowledge base on food security in multifunctional land-use systems in Sri Lanka with a focus on homegardens. Peer-reviewed articles were initially identified using targeted searches in Scopus and Web of Science. Articles were also identified in relevant literature reviews and in the reference lists of the included articles through backward reference list checking (Gough et al. 2012; Karlson and Ostwald 2016), as many relevant articles were not indexed in the two literature search databases. The principal search terms are provided in Table 3.

Table 3. The principal search terms for article titles, abstracts or keywords.

\section{Sri Lanka}

AND

homegarden $O R$ home garden $O R$ agroforestry $O R$ forest garden OR analogue forest OR shifting cultivation $O R$ chena $O R$ household $O R$ farming $O R$ forest $O R$ agriculture OR alley cropping $O R$ intercropping $O R$ family farming $O R$ organic farming $O R$ livelihood OR perennial OR cultivation $O R$ production OR rural OR urban

\section{AND}

Land use OR food security OR food OR crop OR tree OR development OR management OR carbon $O R$ biodiversity $O R$ diversity $O R$ soil $O R$ adaptation $O R$ mitigation OR market $O R$ infiltration $O R$ insurance $O R$ resilience OR vulnerability OR soil fertility OR non-timber

Because the research on homegardens dates back to the early 1970s (Pushpakumara et al. 2012), we refined our literature search from January 1970 to August 2016. Other relevant peer-reviewed and non-peer-reviewed literature were searched in Google Scholar, where the first 100 hits were compared with those already retrieved following Reed et al. (2015). Additional articles were sought through CG Space (a repository of agricultural research outputs and results produced by different parts of CGIAR and partners) using the same approach. 
At the first stage of the screening, we reviewed article titles of all returned hits. Those that adhered to our inclusion/exclusion criteria were passed through to the next stage. The inclusion/exclusion criteria for article titles encompassed: i) food related aspects of multifunctional land-use systems; ii) environmental, economic or social aspects of multifunctional land-use systems; and iii) the study was conducted within Sri Lanka. At the second stage of the screening, we reviewed article abstracts or full-texts that passed through the first stage. The inclusion/criteria for the selection of article abstracts or full-texts encompassed: i) the direct or indirect quantification of a food product or other service, including its weight, volume, nutritional information and a quantification of edible trees/crops; ii) qualitative assessments of aspects related to food security; iii) whether the system is compared to some other agricultural/natural system; iv) direct or indirect impacts both in process and time (e.g., impact of trees, insurance, resilience, soil fertility, long-term investments, etc.); and v) if synergies or trade-offs with other important goals were identified (income, poverty reduction, climate mitigation/adaptation, biodiversity conservation, etc.). After screening all full texts using the aforementioned inclusion/exclusion criteria, the articles were grouped as follows into three main categories based on how they approached food security aspects: i) direct quantification of food security; ii) indirect quantification of foods security; or iii) qualitative aspects of food security with no direct/indirect quantification of food security. Sixteen articles met the inclusion criteria for titles and abstracts but were only available as conference abstracts. These articles were omitted from the analysis.

\section{Results}

\section{Characteristics of the literature}

Ninety-two articles met the inclusion criteria and were screened in full text. Forty-two per cent of the articles $(n=39)$ were retrieved in Web of Science and/or Scopus and $45 \%$ of the articles $(n=41)$ were found through backward reference list checking. In addition, $8 \%$ of the articles $(n=7)$ were categorised as grey literature (unpublished or non-peer-reviewed articles) and $5 \%$ of the articles $(n=5)$ were categorised as student thesis reports.

Historically, the predominant agroforestry systems in Sri Lanka are homegardens, which are also occasionally referred to as forest gardens or analogue forests. This preponderance was also captured in the reviewed literature, where $72 \%(n=66)$ of the articles focused directly or indirectly on different aspects of homegardens mostly and only rarely in comparison with other agroforestry systems (AFS), forest or monocultures. The remaining papers focused either on other agroforestry practices such as intercropping, shifting cultivation or other smallholder systems.

The first publication occurred in 1973, when McConnell and Dharmapala (1973) were the first to assess the structure and functions of Kandyan homegardens. Approximately one fifth of the articles (18\%) focused on this traditional Sri Lankan homegarden system located in the central mid-country wet zone of the island (e.g., Jacob and Alles 1987; Perera and Rajapakse 1991; Pushpakumara et al. 2010); however, since the 1990s other homegarden structures in the intermediate and dry zones have been equally studied.

Approximately one fourth of the articles (26\%) focused on production or management aspects, whereas $31 \%$ of the papers assessed structural, biophysical or ecological aspects. Economic aspects of homegardens are less studied ( $8 \%$ ), whereas $3 \%$ of the papers focus solely on social and cultural aspects of homegardens. Overall, the prevailing focus has been to study the production, management and biophysical aspects of AFS, wherein many of the papers have used multiple methods, complementing field studies and model experiments with questionnaires and interviews. 
Scientific focus for homegardens and food security

Twenty-seven percent $(n=25)$ of all reviewed articles directly quantified aspects related to food and nutrition security. These articles usually analysed parameters such as the number of edible crops, the production (weight and/or volume) of food trees/crops and nutritional information including the nutrient supply of, e.g., vitamins and carbohydrates. Another $51 \%(n=47)$ of the articles indirectly quantified parameters that have relevance for food security including climate, soils, ecosystem services, structural and floristic diversity and economic aspects. Twenty-two percent $(n=20)$ of the articles were categorised as qualitative or more conceptual, providing no self-assessments or quantification of food security aspects (Fig. 1). All screened articles are found in Online Resource 1, where they are divided into whether they consider direct, indirect and qualitative aspects of food security.

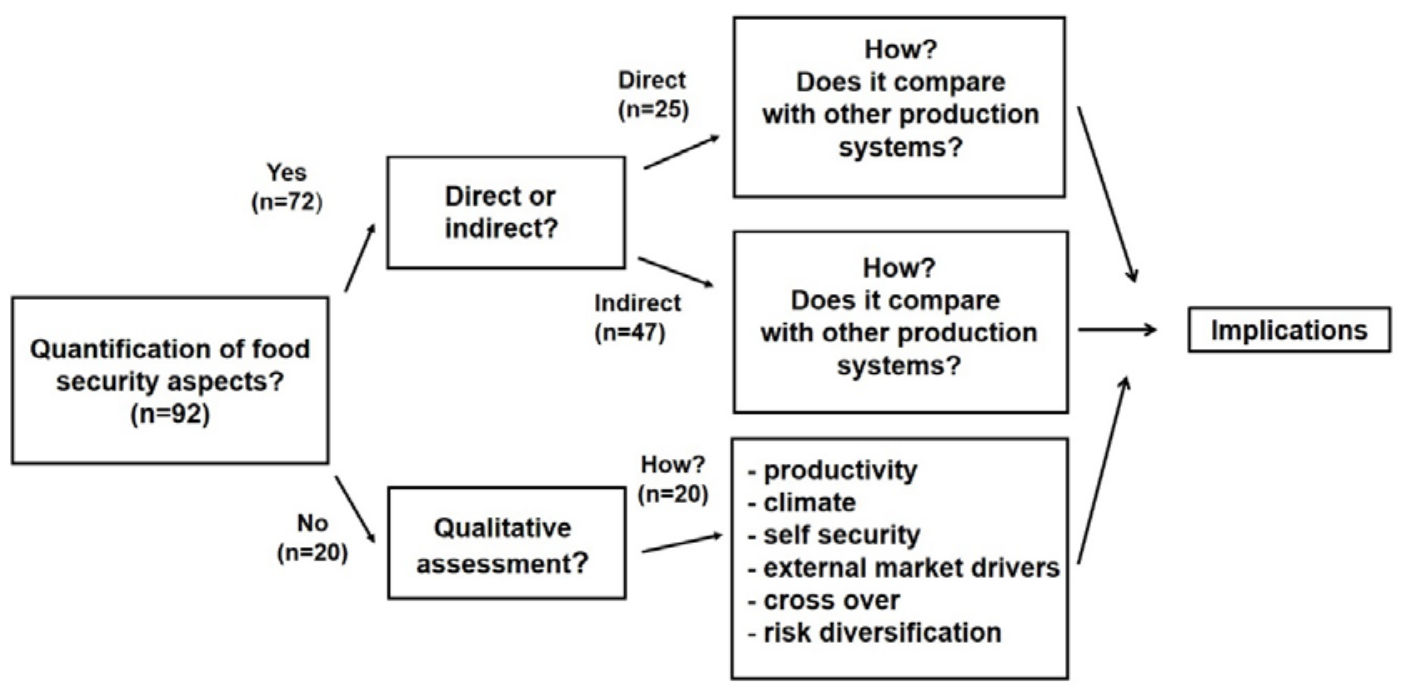

Figure 1 Work flow showing the inclusion/exclusion criteria of screened articles

Direct quantification of food security

Most of the papers that directly quantified aspects related to food and nutrition security claimed that a well-developed homegarden with different annuals and perennials can play a key role in providing a supplemental source of food and income for households, requiring only low input costs on a daily basis (e.g., Weerahewa et al. 2012; Krishnal and Weerahewa 2014; Marasinghe et al. 2015). Three of the 25 articles that directly quantified food security aspects also quantified and compared findings with other land-use systems not defined as homegardens or other AFS (Caron 1995; Illukpitiya and Yanagida 2008; Wijesinghe et al. 2009). In terms of geographical distribution, 14 articles quantified food aspects within a specific district or agricultural zone (dry, intermediate or wet), whereas four papers assessed these aspects between different districts or ecological zones. Two articles presented empirical evidence demonstrating how homegardens can secure food and nutrition security in relation to other countries (both India and Bangladesh).

Of those articles that compared findings with land-use systems other than AFS, Caron (1995) showed that homegardens adjacent to the Sinharaja Man and the Biosphere Reserve can play a critical role in food procurement as result of forest protection polices by shifting the dependency for food and income from the forest onto homegardens with perennial cropping systems. Illukpitiya and Yanagida (2008) found that the most important income source for rural households along forest margins is crop 
farming (34-50\% of their total annual income) followed by off-farm employment (22-31 \%), home gardening (7-17\%) and animal husbandry (2-15\%). Similarly, Marambe et al. (2012a) assessed expenditure patterns of households in the three Sri Lankan ecological zones (wet, intermediate and dry) to identify the contribution from the homegardens to household food security. The results showed that, on average, the food security contribution from homegardens as a ratio of the total food and drinks expenditure (food ratio) was 17, 18 and $29 \%$ for the households (providing no figures on other land uses or other homegarden studies). In another study, Krishnal et al. (2012) calculated food insecurity using the Coping Strategies Index in the Batticaloa district, showing that only $24 \%$ of the households were entirely food secure. Of these households, $74 \%$ had multi-layered homegarden systems, whereas $63 \%$ of the moderately food secure households had multi-layered systems. Multilayered homegarden systems with a mixture of annual and perennial crops are therefore critical to reducing food insecurity. Similarly, species selection and composition defines productivity and are important for enhancing soil moisture and nutrients (e.g., De Costa and Chandrapala 2000).

Most of our empirical data quantify species density or diversity of the majority of food species found in homegardens, often in combination with yield quantification and income levels. Sangakkara and Frossard (2014) are the only authors to have comprehensively analysed the potential of a single crop (yam species Dioscorea alata) to enhance food security and rural development. They suggested that extensive promotion of this crop in homegardens would provide edible carbohydrates with lower inputs than traditional staple crops. Fonseka et al. (2010) quantified food security following the implementation of the Government driven "Api Wawaamu Rata Nagamu" food production programme aimed at enhancing food security in homegardens. It was found that $77 \%$ of selected farmers had fulfilled their vegetable and fruit requirements through home gardening, and, fruit and vegetable consumption reportedly increased by $40 \%$ and $20 \%$ respectively, as a result of the incentives given by the government. Jayawardena and Jayatilaka (1998) found that the potential of Kandyan forest gardens as a supplemental source of food is important but also highly underutilised due to management problems, social trends towards ready-to-eat food, and surplus of food due to seasonality effects.

A SWOT analysis revealed that homegardens have provided many benefits to families affected by the civil war between the Sri Lankan government and the LTTE that occurred from 1983 to 2009, in terms of food security and improved livelihoods (Galhena 2012). In the Jaffna region, both farmers and other stakeholders mentioned the need for better and more access to information, research, education, outreach and advisory services on homegardens to improve their chances of succeeding.

In terms of food nutrition, Dharmasena and Wijeratne (1996) found that homegarden products account for a $12 \%$ share of the recommended per capita calorie requirement for an average person in Sri Lanka. Marasinghe et al. (2015) found a positive significant relationship between the dietary diversity of the household and the plant diversity of homegardens, suggesting that increasing plant diversity in homegardens may achieve food and nutrition security of households. Marambe et al. (2012a) also found that tree species in Bangladeshi, Indian and Sri Lankan homegardens are particularly rich in carbohydrates, vitamin C, riboflavin, iron and vitamin B6, whereas drumstick (pod), sesbania (flower) and guava (raw fruit) were the most nutrient rich. Weerahewa et al. (2011) showed that the intake of vitamin A, vitamin C, calcium and iron from homegarden sources enable an individual to meet $11 \%, 71 \%$ and $11 \%$ of the Recommended Daily Allowance (RDA) of these nutrients. The same authors further recommended enhancing dietary diversity by encouraging the intensification of underutilised fruit and vegetable species in homegardens. 
An increase in publications reporting detailed accounts and analyses of food security aspects is observed beginning in 2010 as a consequence of the increasing debate and impacts related to climate change and soaring food prices (e.g., Weerahewa et al. 2011; Krishnal et al. 2012; Marambe et al. 2012ab; Galhena et al. 2013; Marasinghe et al. 2015). Although there have been recent detailed accounts of the role of food security in homegardens in different districts and agro-ecological zones, no study has thoroughly assessed the real potential of homegardens in providing food security because analyses in relation to other land-use systems at the national level are absent.

Indirect quantification of food security

Of the 48 articles that indirectly quantify food security aspects, $46 \%(n=22)$ compare their findings to other land-use systems not defined as homegardens or other agroforestry systems. In terms of geographical distribution, $79 \%(n=38)$ of the articles indirectly quantity food aspects within a specific district or agricultural zone, whereas the remaining papers did so in several districts or ecological zones.

Globally, since the early 2000s, agroforestry systems have been highlighted as effective measures for adapting to climate and ecosystem changes (Rao et al. 2007; Verchot et al. 2007). This trend is observed in Sri Lanka as well as many recent studies highlight the role of agroforestry systems in relation to either climate change mitigation (Mattsson et al. 2009; 2013; 2014), climate change adaptation (e.g., Weerahewa et al. 2012; Daulagala et al. 2013; De Zoysa and Inoeu 2014; Esham and Garforth 2013) or the provision of ecosystem services (e.g., Mohri et al. 2013; Landreth and Saito 2014). Several authors have also assessed different soil conditions as a measure of crop productivity. For example, establishment of AFS on adjacent degraded lands can lead to accumulation of soil organic matter and nutrients in the topsoil while increasing aggregate stability (e.g., Mapa and Gunasena 1995; Siddique et al. 2007).

Previous studies show that homegardens have good capacity for carbon storage in above ground biomass, similar to secondary forests (Mattsson et al. 2013; Mattsson et al. 2014). Climate finance could therefore be a new source of funds - via climate intervention programmes focused on reduced deforestation and reforestation. Linking mitigation benefits to potential carbon markets could therefore be a new income source, provided there are price increases (ranging from 1-13 USD on the major markets in 2016 (World Bank 2016).

Five papers deals with water management related issues. Compared to other intensive agricultural systems, AFS rely on rainfed irrigation for survival and limited supply of water during cropping seasons adversely affects crop production. For example, Wagachchi and Wiersum (1996) found that cultivation of AFS around small reservoirs allows the combined management of vegetation and water resources while capturing rainwater from the farmer's own roof and conserving it for subsequent use in homegardening can in many cases be sufficient to be used as the only irrigation source for home gardens (Jayasuriya et al. 2014).

Backed by local government support to enhance local food production, Bandara (2015) reported an improving attitude regarding homegarden cultivation in urban homegardens given the increasing prices of agricultural products and the increased use of fertilisers and pesticides in monoculture cultivations. According to Korale-Gedara et al. (2015), the commercialisation and intensification of homegardens resulting from population pressures, socio-economic changes and government-driven campaigns in the past to cope up with increasing food prices have not always decreased plant diversity in homegardens. Conversely, it has been argued that such intensification may cause the opposite effect. For example, Landreth and Saito (2014) observed that the traditional balance of homegarden systems is changing as households and communities now often respond to new change 
drivers by simplifying cultivation to be more commercial, less diverse or by abandoning cultivation altogether.

Suthakar and Bui (2008) found that many agricultural lands, including homegardens, were abandoned and regenerated back to forests or bushlands during the war between the government and the LTTE that occurred from 1983 to 2009. Nevertheless, homegardens played a key role during the war and contributed to food security, income generation, and livelihoods in the Northern region of Sri Lanka through the production of a diverse set of vegetables, fruits, herbs, plantation crops, ornamentals, and livestock products (Galhena 2012) and may continuously offer a potential toward establishing small-scale business opportunities for the food insecure portion of the population in this region. Jayavanan et al. (2014) further showed that live fences demarcating the boundaries of homegardens and farmlands in the Jaffna region play an important role in providing protection, regulation, support, food and cultural services to households by forming networks of natural habitats.

Qualitative aspects of food security

Articles $(n=20)$ that discussed qualitative aspects related to food security focused either on: i) production and management; ii) climate; iii) AFS as self-secure systems; iv) the role of external drivers; or v) AFS as an arena for multidisciplinarity and a mixture of knowledge. Impacts, synergies and trade-offs were analysed within/between these aspects.

Eighty-five per cent of these papers ( $n=17)$ are descriptive reviews or discussion papers. In terms of production and management, the role of AFS development is often discussed in relation to biophysical constraints due to unsustainable land-use management in the past. Ulluwishewa (1991) and de Costa and Sangakkara (2006) argue that low soil fertility, erosion and sub-optimal crop management, as a consequence of modern development efforts and increased population pressures in the late 1900s, has resulted in dry upland AFS having less importance than before in terms of food supply, resulting in food shortages and food insecurity. A revival of traditional practices, such as adding organic matter directly to soils, green manuring and mimicking forest ecosystems through agroforestry, are therefore needed. Nuberg et al. (1994) also stress that the development of homegarden systems anywhere must be sensitive to both the domestic and commercial needs of the population and to the degree to which these are met by other land-use types in the landscape. Ranasinghe and Newman (1993) argue that agroforestry should not be regarded as a panacea but rather a tool, which if used carefully is capable of solving many problems created by unsustainable forestry and agricultural practices in Sri Lanka.

Provided high economic development, urbanisation and increasing demand for land, land available for homegardens is also decreasing. For example, young people often migrate to cities for work (Nuberg et al. 1994; Ranasinghe 2010). Most urban properties only have enough space to build a house and leave little room for a garden, causing traditional agroforestry knowledge to disappear. The rural-to-urban transition also makes it more difficult and expensive for the remaining rural families to manage their gardens due to a lack of labour, which in turn forces families to sell their gardens, spurring homegarden fragmentation (Ranasinghe 2010). Market fluctuations of different food crops and trees also contribute to these challenges. Land fragmentation may therefore constrain the traditional knowledge of maintaining homegardens (Landreth and Saito 2014).

What is good about homegardens in terms of food security?

In line with the rumours and rhetoric, homegardens in Sri Lanka do offer food security in dire times by providing multiple benefits and services, particularly for the poorer segment of the land users. This includes delivering a mixture of annual and perennial crops, which provide a range of supplemental nutritious products throughout the year at a low input cost highlighting the land use's status as a 
marginal farming practice (Weerahewa et al. 2012; Krishnal and Weerahewa 2014; Marasinghe et al. 2015). This connects to the notion that homegardens are the poor land users' safety net or insurance when other agricultural activities fail or income is decreasing. On the same note, by using the Coping Strategy Index, Krishnal et al. (2012) showed that households with homegardens in one district dominated the group that was entirely food secure. However, the downside of the situation as described above is that the technology development, evolution of practice or expansion of this type of land-use is inherently limited.

Species diversity, species density and the food nutrition provided by homegardens are valued as positive (Dharmasena and Wijeratne 1996; Fonseka et al. 2010) not only by quantity but also in terms of quality (Vitamin A, B6 and C, calcium, riboflavin, and iron). The size of the homegardens might have an effect here as it has been showed that tree density decreased with homegarden size (Mattsson et al. 2014). This implies that there is a required closeness and intensity built into the land-use system for it to be highly productive and that it tends to get weaker with growing size. This contradicts the desire to expand and extrapolate homegardens to enhance its positive impacts.

In pace with population increase and urbanization in particular, the role of homegardens is greatly discussed in Sri Lanka. For example the attitude towards urban farming is positive and prioritised by policy makers (Bandara 2015). Apart from homegardens' high species density and diversity as well as their role as buffer against price fluctuations they have indirect positive impacts on food production and food security as they cool the environment during heat and have high infiltration capacity during rains. In Sri Lanka and elsewhere, homegardens are evidently climate smart land-use systems, achieving mitigation and adaption to climate change.

Knowledge gaps regarding homegardens and food security Seven types of knowledge gaps have been identified in relation to homegardens and food security. Pushpakumara et al. (2012) presented the following four key issues that require further attention in homegarden research if food and nutrition security is to be achieved through homegardening: (i) an improved understanding of the system and a planned introduction and utilisation protocol for plant/tree/animal species; (ii) an understanding of the reasons for omitting the animal component in the majority of homegardens in Sri Lanka and take appropriate measures to include them in the system (rearing animals in homegardens in Sri Lanka is rather limited compared to other countries in South Asia and only two of our articles assessed livestock functions in relation to food security); (iii) the selection of species based on unique problems in the area (e.g., malnutrition due to vitamin A, iron deficiencies, poverty); and (iv) the integration of homegarden skills training with health and nutrition education. Such measures could include on-farm research and demonstration sites where collaboration between research, practitioners and farmers could increase dissemination and upscaling.

A fifth knowledge gap area is water management practices. For example, little is known about how beneficial different plants and trees are in terms of water management and how much water they consume (Renault et al. 2000).

Measures to reduce harvest losses and improve the commercialisation, market channels and added value of homegardens without risking their sustainability and diversity is another knowledge gap little studied, however needed since these parameters are primary objectives according to users (Batagalle et al. 1996). Landreth and Saito (2014) argue that there have been recent attempts to promote homegarden products in the international market by obtaining international certifications. However, government and development programmes highlighting only commercialisation aspects risk 
simplifying the production in homegardens of any specific species. Therefore, the impacts and consequences from such interventions on ecosystem services and food security require further study.

Gender aspects were mentioned in eight articles, although few authors have studied these aspects in detail, hence a topic that could benefit from more research. Homegardens are typically managed by women who use them to fulfil a variety of household needs, from feeding their children to cultivating vegetables and spices that are important ingredients in local diets, as well as generating additional household income (Fonseka et al. 2010; Galhena 2012). Jawardena and Jayatilaka (1998) investigated the role of gender to meet food security requirements. They found that women tend to be the primary decision-makers and managers of homegardens and are often in charge of growing secondary crops that diversify production and provide for a healthy household diet, contributing to greater household resilience and food security, whereas men tend to grow tree crops and are engaged in marketing homegarden products. Caron (1995) observed that women participate in many more income generating activities than men, whereas Bandara (2015) argues that the daily management of kitchen gardens, especially by women, contributes to their non-paid labour for both short- and long-term benefits. World Bank; CIAT (2015) also state that key sustainable management practices such as rainwater harvesting techniques, crop diversification and livestock integration, mulching and thatching, and micro-irrigation are predominantly undertaken by women in homegardens. Such activities represent important entry points for advancing adaptation, mitigation, and productivity goals but also for acknowledging and encouraging women's critical role as knowledge heirs, decision makers and environmental stewards (ibid). The importance of including women through participation and empowerment has also been highlighted in many government and development programmes since the early 2000s (Ranasinghe 2003; Ranasinghe 2010; Galhena 2012).

Science to policy implications

In Sri Lanka's current development policy framework, the primary objectives are to incorporate climate change adaptation into national planning and development and to minimise climate change impacts on food security. Related examples include the national community based REDD+ programme, which has identified increasing the productivity in homegardens as a central activity to mitigating climate change by addressing the drivers of deforestation and forest degradation and meeting national timber and fuel wood requirements (UN-REDD 2015). As mentioned previously, homegarden developments are also core components in many development aid programmes including the AusAid funded Sri Lanka community forestry programme and GEF (Global Environmental Facility) Small Grants Programme, which aim to reduce deforestation and forest degradation, support livelihoods and contribute to poverty reduction (UNDP 2012).

Since the early 2000s, there have been many governmental programmes focused on increasing food production in homegardens. Examples include the government programme "Api Wawamu Rata Nagamu" (Let us grow, and uplift the nation), launched in 2007, which aimed to develop 375000 homegardens, the national tree planting programme "Deyata Sevana" and the most recent programme "Divi Neguma" (Livelihood Development), whose goal it is to establish 2.5 million homegardens as a means for achieving self-sufficiency in vegetable cultivation and reducing vegetable prices (Kumari et al. 2009). Information about the impacts of those programmes has been scarce, although it was reported that vegetable and fruit consumption have increased (Fonseka et al. 2010). Many of the recent national programmes promoting homegarden development have been criticised as being short-term solutions and have had mixed outcomes due to a lack of continuous monitoring, insufficient stakeholder engagement and an absence of clearly defined objectives. For example, the core strategies of national development programmes to increase homegarden production have been to provide seeds, plants or poultry to farmers, but the species and breeds provided have not always 
matched farmer's needs and knowledge capacities. Additionally, programmes whose primary focus has been food security have tended to neglect other environmental drivers such as increased wild animal incursions, water limitations and other livelihood aspects (Landreth and Saito 2014).

Science to policy linkages can be improved by information sharing through all phases of development programmes including discovery and deployment, as a barrier to creating effective policies has been that stakeholders often view homegardens differently and have different goals and expectations about how to best develop and improve them. Future initiatives and development programmes promoting food production in homegardens therefore need to be more long-term and inclusive than they are currently, exploiting potential synergies and trade-offs between meeting farmers' primary objectives related to income and food security, while also achieving larger societal and environmental objectives of climate change, ecosystem services and biodiversity conservation. Due to different environmental and social-economical possibilities, needs and drivers, programs could also benefit from being context specific, such as distinguishing between dry and wet zone homegardens or the difference between rural and urban practices in terms of, for example, land and labour availability,

One of the strongest pieces of food security evidence found in our data suggests that poor people in particular benefit from the products that homegardens provide. To avoid preserving a system whose sole aim is to encourage people to collect fruits and nuts, the policy focus should further expand the use and benefits of homegardens, where value addition and market access can be promoted.

\section{Discussion}

The Sri Lankan case of homegardens as a multifunctional land-use system and its positive impact in times of climate change and food insecurity is not unique. From other parts of the globe, similar evidence of different types of agroforestry and its wanted impact to mitigate and adapt climate change and food security is increasing in the scientific literature (e.g., Gray et al. 2014; Lipper et al. 2014; Mbow et al. 2014b). The increased scientific focus on food security aspects in homegardens globally as well as in Sri Lanka is likely due to increasing costs for food production, the potential for homegardens to address the inadvertent consequences of climate change and their serving as an alternative to intensive farming and commercial forestry practices by increasing the availability, affordability and consumption of diverse, organic and nutrient-dense food products.

Various authors have argued that most studies on homegarden systems globally focus on the garden's physical structure, function and ecological structure or a specific ecosystem service in a particular study area (e.g., Abdoellah et al. 2006; Kehlenbeck et al. 2007; Mohri et al. 2013). This observation is in accordance with our results as well as a majority of the assessed articles were generated from short-term studies on randomly selected homegardens in different locations studying these land-use systems in isolation, whereas long-term studies using permanent sampling techniques are absent.

Our findings are in accordance with the previous review by Pushpakumara et al. (2012), who argue that policy decisions are made without concrete evidence from the research conducted as many studies on homegardens are provided as student reports and abstract publications with limited access for researchers, policy makers and general practitioners. In addition, many publications provide few details on the methodologies used, resulting in a repetition of research areas, while many critical research areas remain unexplored.

Several researchers suggest that the diversification and intensification of homegardens coupled with management practices such as rainwater harvesting and organic waste composting would help to improve food and nutrition security (e.g., Galhena 2012; Dubbeling 2015). This could be accomplished 
through awareness campaigns, technical assistance and the effective utilisation of resources by considering location specific (biophysical) and household specific (socio-economic) diversity (Wijeratne et al. 2010), such as dry versus wet areas or rural versus urban homegardening. However, such interventions must be performed with care as intensification could increase production but could also reduce output stability and resource use efficiency and enhance the over-exploitation of the resource base (Krishnal and Weerahewa 2014). In an era of globalisation that includes an increasing intensification of other land-use practices, infrastructure development and new employment opportunities, the dependence of farm families on their gardens for food needs and dietary quality will likely decrease (Kuruppu et al. 2015). To maintain and develop the multi-storied and multi-species nature of homegardens, it will therefore be important to develop means for increasing the profitability of homegarden systems while maintaining households' livelihoods and ecosystem services such as biodiversity and water regulation (Landreth and Saito 2014).

This review demonstrates that homegardens and other agroforestry systems in Sri Lanka are an integral part of smallholder agriculture and provide a supplemental source of food and income for households at low input costs on a daily basis. Although there are many studies concerning food security aspects of homegardens in Sri Lanka, the interlinkages with other land-use systems including the impacts, trade-offs and synergies from food production remain relatively unexplored.

Additionally, no available studies comprehensively assess the potential of homegardens to support food and nutrient supply in relation to environmental, social and economic aspects at a landscape- or national level, making it difficult to assess the true contribution of homegardens to food security. Hence, long-term transdisciplinary and data-dense research programmes, with clear monitoring and evaluation methods based on clear indicator frameworks, are needed to understand the dynamics of homegardens in relation to changes in society and the environment. Such programmes are necessary to understand, recognise and develop policies and measures that can merge the aspirations of individual farmers with the long-term social and environmental objectives desired by society in general.

\section{Conclusions}

Four major conclusions can be drawn from our assessment.

Firstly, we found that out of 92 articles, $27 \%$ are focusing on direct linkages between homegardens and food security through evidence of supplement source of food. Fifty-one percent of the articles are focusing on indirect linkages dominated by records of improved ecosystem services while $22 \%$ of the articles are being qualitative and conceptual consisting mostly of descriptive reviews or discussion papers.

Secondly, aligned with earlier studies we can show that homegardens in Sri Lanka are the poor farmers' insurance and safety-net in dire food situations, giving additional nutrition and calories. Inherent in this fact is the general lack of attention to commercial or market interest and technical development in the literature, which can be a drawback for expansion, experimentation and overall development or might be its success for sustainability.

Thirdly, we identify seven areas where additional research would be beneficial. These areas include i) improved understanding of the system by using utilization protocols for practical application, ii) livestock in homegardens, iii) species selection for health needs, iv) promoting homegardens within education for health and sustainability, v) the nexus between homegardens and water management, vi) the role of commercialization (e.g., harvest loss, market channels, added value, certification protocols) and viii) gender aspects. 
Lastly, for policy application our data suggests that a higher degree of inclusiveness of relevant stakeholders aligned with long-term commitments would generate greater output of homegardens in terms of food security. Further, a more context specific protocol where biophysical parameters as well as socio-economical drivers, needs and limitations are differentiated, which would reduce unwanted effects.

\section{Acknowledgements}

We thank the AgrifoSe2030 programme for the financial support provided. Also many thanks to Professor D.K.N.G Pushpakumara and Professor Buddhi Marambe for providing their insights and thoughts. We also thank Gert Nyberg and Daniel Ternald for their constructive comments on the manuscript.

\section{References}

Abdoellah OS, Hadikusumah HY, Takeuchi K, Okubo S, Parikesit G (2006) Commercialization of homegardens in an Indonesian village: vegetation composition \& functional changes. Agrofor Syst 68: $1-13$

AgStat (2016) Pocket book of Agricultural Statistics. Socio Economics and Planning Centre. Department of Agriculture, Peradeniya.

Ali A, Mattsson E (2016) Individual tree size inequality enhances aboveground biomass in homegarden agroforestry systems in the dry zone of Sri Lanka. Sci Total Environ 575:6-11

Bandara TWMTW (2015) Modern Trends and Distribution Patterns of Kitchen Gardens in Sri Lanka (A Case Study in Biyagama area). Soc Sci Humanit Rev 2:2279-3933

Batagalle NK, Kotagama HB, Senaratne DMAH (1996) An economic assessment of the sustainability of traditional agroforestry systems: the case of Kandyan forest gardens Proceedings of the Second Annual Forestry Symposium 1996 Management and Sustainable Utilization of Forest Resources. Sri Lanka, 6-7 December 1996.

Bustamante M, Robledo-Abad C, Harper R, Mbow C, Ravindranath NH, Sperling F, Haberl H, Pinto AD, Smith $\mathrm{P}$ (2014) Co-benefits, trade-offs, barriers and policies for greenhouse gas mitigation in the agriculture, forestry and other land use (AFOLU) sector. Glob Chang Biol 20:3270-3290

Caron CM (1995) The role of nonwood tree products in household food procurement strategies: profile of a Sri Lankan village. Agrofor Syst 32:99-117

Daulagala C, Weerahewa J, Marambe B, Pushpakumara G, Silva P, Punyawardena R, Premalal S, Miah G, Roy J, Jana S (2013) Socio-Economic Characteristics of Farmers Influencing Adaptation to Climate Change: Empirical Results from Selected Home Gardens in South Asia with Emphasis on Commercial Orientation, Sri Lanka J Adv Soc Stud ISSN: 2012-9149.

De Costa WAJM, Sangakkara UR (2006) Agronomic regeneration of soil fertility in tropical Asian smallholder uplands for sustainable food production. J Agr Sci 144:111-133 
De Costa WAJM, Chandrapara AG (2000) Competition between six hedgerow tree species and mungbean in the mid country intermediate zone. J Natl Sci Found Sri 28:113-125

De Zoysa M, Inoue M (2014) Climate Change Impacts, Agroforestry Adaptation and Policy Environment in Sri Lanka. Open J For 4:439-456

Dharmasena KH, Wijeratne M (1996) Analysis of nutritional contribution of home gardening. Tropenlandwirt 97:149-158

Dubbeling M (2015) Integrating urban agriculture and forestry into climate change action plans: Lessons from Western Province, Sri Lanka and Rosario, Argentina. RUAF Foundation.

Esham M, Garforth C (2013) Agricultural adaptation to climate change: Insights from a farming community in Sri Lanka. Mitig Adapt Strateg Glob Chang 18:535-549

FAO (2009) Sri Lanka Forestry Outlook Study. Asia Pacific Forestry Outlook Sector Outlook Study II, Working Paper No. APFSOS II/WP/2009/29, Bangkok, FAO Regional Office for Asia and the Pacific.

Fonseka RMF, Pathmaraja S, Kodiweera NKAC (2010) Status of home gardening in Mahaweli System H area as influenced by the government food production drive - "Let us cultivate and uplift the nation". Sri Lankan J Agricu Sci 47:62-73

Galhena DH (2012) Home Gardens for improved food security and enhanced livelihoods in northern Sri Lanka. PhD Thesis. Michigan State University.

Galhena DH, Freed R, Maredia KM (2013) Home gardens: a promising approach to enhance household food security and wellbeing. Agric Food Secur 2:48-62

Gough D, Oliver S, Thomas J (2012) An Introduction to Systematic Reviews. SAGE Publications, London.

Government of Sri Lanka (2015) Food Production National Programme 2016-2018. Presidential Task Force on National Food Production. Available at:

http://www.agrimin.gov.Ik/web/images/pdf/FoodProductionBook-English.pdf Accessed September 5, 2016.

Gray L, Guzman P, Glowa KM, Drevno AG (2014) Can home gardens scale up into movements for social change? The role of home gardens in providing food security and community change in San Jose, California. Local Environ 19:187-203

Hochegger K (1998) Farming like the forest: traditional homegarden systems in Sri Lanka. Tropical Agroecology, Margraf Verlag, Weikersheim, 203 pp.

Illukpitiya P, Yanagida JF (2008) Role of income diversification in protecting natural forests: evidence from rural households in forest margins of Sri Lanka. Agrofor Syst 74:51-62

Jacob VJ, Alles WS (1987) The Kandyan gardens of Sri Lanka. Agrofor Syst 5:123-137 
Jayasuria N, Navaratne CM, Weerasignhe KDN, Nawarathna B, Adams R (2014) Roof Runoff Capture for Home Garden Crop Cultivation in Sri Lanka J Irrig Drain Eng 140: 05014004

Jayawardena LNAC, Jayatilaka MWAP (1998) Role of gender in the optimum use of Kandyan forest gardens as a source to food to meet food security requirements. In: Multipurpose Tree Species in Sri Lanka - Fuelwood Energy and Gender Issues.

Jayavanan K, Pushpakaumara DKNG, Sivachandran S (2014) Role of live fence agroforestry in Jaffna peninsula. Trop Agric 162:25-44

Karlson M, Ostwald M (2016) Remote sensing of vegetation in the Sudano-Sahelian zone: a literature review from 1975 to 2014. J Arid Environ 124:257-269

Kehlenbeck K, Arifin HS, Maass B (2007) Plant diversity in homegardens in a socio-economic and agroecological context. The Stability of Tropical Rainforest Margins: Linking Ecological, Economic and Social Constraints of Land Use and Conservation. Springer Verlag, Berlin, pp.297-319.

Korale-Gedara P, Weerahewa J, Pushpakumara G, Kodithuwakku SS (2015) Commercial Orientation and its Effects on Plant Diversity in Homegardens: An Empirical Investigation of Rural Households in Sri Lanka. Sri Lanka J Agric Econ 14:17-42

Krishnal S, Weerahewa J, Gunaratne LHP (2012) Role of Homegardens in Achieving Food Security in Batticaloa District, Sri Lanka. International Conference on Economics and Finance Research IPEDR. IACSIT Press, Singapore. 32 pp.

Krishnal S, Weerahewa J (2014) Structure and species diversity of traditional homegardens in Batticaloa district. J Agric Sci 9:139-146

Kudavidanage EP, Wanger TC, de Alwis C, Sanjeewa S, Kotagama SW (2011) Amphibian and butterfly diversity across a tropical land-use gradient in Sri Lanka; implications for conservation decision making. Animal Conservation doi:10.1111/j.1469-1795.2011.00507.x

Kumar BM (2006) Carbon sequestration potential of tropical homegardens. Tropical Homegardens: A Time-tested Example of Sustainable Agroforestry. Eds. B.M. Kumar and P.K.R. Nair. pp 185-204. Springer Science, Dordrecht.

Kumar BM, Singh AK, Dhyani SK (2012) South Asian agroforestry: traditions, transformations, and prospects. In: Nair PKR, Garrity D (eds.) Agroforestry - The Future of Global Land Use. Advances in Agroforestry Volume 9. Springer, Dordrecht, the Netherlands. pp 359-389

Kumari MAS, Kansuntisukmongkol K, Brockelman WY (2009) Plant diversity in home gardens and its contribution to household economy in suburban areas in Sri Lanka. Env Nat Resour J 7:12-30

Kuruppu N, Willie R (2015) Barriers to reducing climate enhanced disaster risks in Least Developed Country-Small Island trough anticipatory adaptation. Weather and Climate Extremes 7:72-83

Landreth N, Saito O (2014) An Ecosystem Services Approach to Sustainable Livelihoods in the Homegardens of Kandy, Sri Lanka. Aust Geogr 45:355-373 
Lipper L, Thronton P, Campbell B.M. et al. (2014) Climate-smart agriculture for food security. Nat Clim Chang 4:1068-1072.

Mapa RB, Gunasena HPM (1995) Effect of alley cropping on soil aggregate stability of a tropical Alfisol. Agrofor Syst 32:237

Marambe B, Weerahewa J, Pushpakumara G, Silva P, Punyawardena R, Premalal S Miah G, Roy J (2012a) Vulnerability of homegarden eco-systems to climate change and its impacts on food security in south Asia. Asia-Pacific Network for Global Change Research, Kobe, Japan

Marambe B, Pushpakumara G, Silva P, Weerahewa J, Punyawardena BVR (2012b) Climate Change and Household food security in homegardens of Sri Lanka. International Conference on Climate Change Impacts and Adaptation for Food and Environmental Security, (Eds: HPM Gunasena, HAJ Gunathilake, JMDT Everard, CS Ranasinghe, and AD Nainanayake), pp 87-100, Colombo, Sri Lanka.

Marambe B, Punyawardena R, Silva P, Premalal S, Rathnabharathie V, Kekulandala B, Nidumolu U, Howden M (2015) Climate, Climate Risk, and Food Security in Sri Lanka: Need for Strengthening Adaptation Strategies. Handbook of Climate Change Adaptation. Springer-Verlag Berlin.

Marasinghe WMDK, Edirisinghe JC, Lokuge LDMN (2015) Linking Plant Diversity and Dietary Diversity of Home Gardens: Examining the Nexus Through Structural Equation Modelling. J Env Prof Sri Lanka: 4-2:47-57

Mattsson E, Ostwald M, Nissanka SP, Holmer B, Palm M (2009) Recovery of coastal ecosystems after tsunami event and potential for participatory forestry CDM - examples from Sri Lanka. Ocean Coast Manage 52:1-9

Mattsson E, Ostwald M, Nissanka SP, Marambe B (2013) Homegardens as a multi-functional land use strategy in Sri Lanka with focus on carbon sequestration. AMBIO 42:892-902

Mattsson E,Ostwald M, Nissanka SP, Pushpakumara DKNG (2014) Quantification of carbon stock and tree diversity of homegardens in the dry zone area of Sri Lanka. Agrofor Syst 89:435-445

Mbow C, van Noordwijk M, Prabhu R, Simons AJ (2014a) Knowledge gaps and research needs concerning agroforestry's contribution to sustainable development goals in Africa. Curr Opin Environ Sustain 6:162-170

Mbow C, van Noordwijk M, Luedeling E. et al. (2014b) Agroforestry solutions to address food security and climate change challenges in Africa. Curr Opin Environ Sustain 6:61-67

McConnell DJ, Dharmapala, KAE (1973) The economic structure of Kandyan forest garden farms. Small forest garden farms in the Kandy district of Sri Lanka. Farm Management Diversification Report No. 7. UNDP/SF/FAO Diversification Project, Peradeniya, Sri Lanka.

McConnell DJ (2003) Nature, The Forest Farms of Kandy and Other Gardens of Complete Design. Ashgate Publishing, 544 pp. 
Minang PA, van Noordwijk M, Swallow BM (2012) High-carbon-stock rural development pathways in Asia and Africa: improved land management for climate change mitigation. In: Nair PKR, Garrity DP (eds) Agroforestry: the future of global land use. Springer, The Netherlands, pp 127-143 Kumar

Minang PA, Duguma LA, Bernard FO, Mertz O, van Noordwijk M (2014) Prospects for agroforestry in REDD? Landscapes in Africa. Curr Opin Environ Sustain 6:78-82

Ministry of Mahaweli Development and Environment (2015) National Adaptation Plan for Climate Change Impacts in Sri Lanka 2016-2025. Available at:

http://www.climatechange.Ik/NAP/NationalAdaptationPlan_RevisedFinal.26.10.2015.pdf Accessed November 20, 2016.

Mohri H, Lahoti S, Saito O, Mahalingam A, Gunatilleke N, Irham Hoang VT, Hitinayake G, Takeuchi K, Herath S (2013) Assessment of ecosystem services in homegarden systems in Indonesia, Sri Lanka, and Vietnam. Ecosyst Serv 5:124-136

Nuberg IK, Evans DG, Senanayake R (1994) Future of forest gardens in the Uvan Uplands of Sri Lanka. Environ Manage 18:797-814

Pathmanathan $\mathrm{H}$ (2014) Strengthening resilience and food security through the development of agroforestry in post-war Kilinochchi, Sri Lanka. Master thesis. University of Waterloo, Ontario, Canada.

Pathmasiri, EHGC, Bandara TWMTW (2016) Place Theory for Studying Biodiversity of Kandyan Home Gardens in Sri Lanka. Int J Sci Res Publ 6:154-159

Perera AH, Rajapakse RMN (1991) A baseline study of Kandyan forest gardens of Sri Lanka: structure, composition and utilisation. For Ecol Manage 45:269-280

Pushpakumara DKNG, Wijesekara A, Hunter DG (2010) Kandyan homegardens: A promising land management system in Sri Lanka. In Sustainable use of biological diversity in socioecological production landscapes, ed. C. Belair, K. Ichikawa, B.Y.L. Wong, and K.J. Mulongoy, 102-108. Background to the 'Satoyama Initiative for the benefit of biodiversity and human well-being. Secretariat of the Convention on Biological Diversity, Montreal, Canada.

Pushpakumara DKNG, Marambe B, Silva GLLP, Weerahewa J, Punyawardena BVR (2012) A review of research on homegardens in Sri Lanka. The status, importance and future perspective. Trop Agric 160:55-125

Ranasinghe TT (2003) A novel living agricultural concept in urban communities: Family Business Garden, Int Jf Sust Dev World Ecol 10:239-245

Ranasinghe WA, Newman C (1993) Agroforestry research and practice in Sri Lanka. Agrofor Syst 22: 119-130

Ranasinghe H (2010) Traditional Home Gardens in Sri Lanka: A sustainable Agro-Ecosystem with integrated land management. Economic Review: April/May 2010. 
Rao KPC, Verchot LV, Laarman J (2007) Adaptation to climate change through sustainable management \& development of agroforestry systems. J SAT Agric Res 4:1-30

Reed J, Deakin L, Sunderland T (2015) What are the 'integrated landscape approaches' and how effectively have they been implemented in the tropics: a systematic map protocol. Environ Evid 2015;4:2

Renault D, Hemakumara M, Molden D (2000) Importance of water consumption by perennial vegetation in irrigated areas of the humid tropics: evidence from Sri Lanka. Agric Water Manage $46: 215-230$

Sangakkara UR, Frossard E (2014). Home gardens and Dioscorea species - A case study from the climatic zones of Sri Lanka J Agr Rural Dev Trop 115:55-65

Sangakkara UR, Frossard E (2016) Characteristics of South Asian rural households and associated homegardens - A case study from Sri Lanka. Trop Ecol 57:765-777

Santika T, Meijaard E, Wilson KA (2015) Designing multifunctional landscapes for forest conservation. Environ Res Lett 10:114012

Senanayake FR (1987) Analog forestry as conservation tool. Tiger Pap 15:25-28

Siddique I, Gutjahr C, Seneviratne G, Breckling B, Ranwala SW, Alexander IJ (2007) Changes in soil chemistry associated with the establishment of forest gardens on eroded, acidified grassland soils in Sri Lanka. Biol Fertil Soils 44:163-170

Suthakar K, Bui EN (2008) Land use/cover changes in the war-ravaged Jaffna Peninsula, Sri Lanka, 1984-early 2004. Singap J Trop Geogr 29:205-220

Ulluwishewa R (1991) Modernization versus sustainability: disintegrating village agroecocomplexes in the Dry Zone of Sri-Lanka. Env Conserv, Cambridge Univ Press 18:103-109

UN DESA (2015) United Nations Department of Economic and Social Affairs, Population Division. World Population Prospects: The 2015 Revision, Key Findings and Advance Tables. Working Paper No. ESA/P/WP.241

UNDP (2012) Project document - Sri Lanka Community Forestry Programme. Available at: http://www.lk.undp.org/content/srilanka/en/home/operations/projects/environment_and_energy/s ri-lanka-community-forestry-programme-.html Accessed November 8, 2016.

UNFCCC (2016) Intended Nationally Determined Contributions. Ministry of Mahaweli Development and Environment, Sri Lanka (Date of submission 2016-04-25). http://www4.

unfccc.int/submissions/INDC/Submission\%20Pages/submissions.aspx Accessed June 1, 2016.

UN-REDD (2015) Community Based REDD+ (CBR +) Country Plan for Sri Lanka, Available at: http://www.redd.lk/web/images/contents/documentcentre/Community-Based-REDD-Summary.pdf. Accessed November 8, 2016. 
Wagachchi HR, Wiersum KF (1996) Water management in agroforestry systems: integrated buffalo ponds and forest gardens in Badulla district, Sri Lanka. Agrofor Syst 35:291-302

van Noordwijk M, Agus F, Dewi S, Purnomi H (2014) Reducing emissions from land use in Indonesia: motivation, policy instruments and expected funding streams. Mitig Adapt Strateg Glob Change 19:677-692

Verchot LV, Van Noordwijk M, Kandjii S, Tomich T, Ong C, Albrecht A, Mackensen J, Bantilan C et al. 2007. Climate change: Linking adaptation and mitigation through agroforestry. Mitig Adapt Strateg Glob Change 12:901-918

Weerahewa J, Wijerathne B, Pushpakumara DKNG (2011) Homegardens as asource of micronutrients: an analysis of food harvested from homegardens inKandy, Kurunegala and Batticaloa districts in Sri Lanka. Trop Agric 159:107-134

Weerahewa J, Pushpakumara G, Silva P, Daulagala C, Punyawardena R, Premalal S, Miah G, Roy J (2012) Are homegarden ecosystems resilient to climate change? An analysis of the adaptation strategies of homegardeners in Sri Lanka. APN Sci Bull 2:22-27

Wijeratne B, Weerahewa J, Pushpakumara DKNG (2010) Home Gardens as a Source of Micronutrients: An Empirical Analysis of Home Gardens in Kandy, Kurunegala and Batticaloa Districts. Sri Lanka Agricultural Economics Association: 4th Annual Research Forum.

Wijesinghe DB, Egodawatta WCP, Sangakkara UR, Pushpakumara DKNG, Stamp P (2009) Productivity of Maize (Zea mays L.) and Mung bean (Vigna radiate L.Wikzek) in Homegardens and Cropping Fields under Subsistence Conditions Trop Agric Res 21:168-176

World Bank; CIAT (2015) Climate-smart agriculture in Sri Lanka. CSA country profiles for Africa, Asia, and Latin America and the Caribbean series. Washington D.C.: The World Bank Group

World Bank (2016) State and Trends of Carbon Pricing 2016 (October), World Bank, Washington, DC. 